\title{
PERILAKU MENGAKSES PORNOGRAFI ELEKTRONIK PADA REMAJA (Studi di SMP N di Kabupaten Pati)
}

\section{ELECTRONIC ACCESS PORN BEHAVIOR IN ADOLESCENT (Study in Junior Midle School at Pati Regency)}

\author{
Siti Qorrotu Aini \\ Kantor Penelitian dan Pengembangan Kabupaten Pati \\ Email: ainiqurrotu85@gmail.com
}

Naskah Masuk : 7 Oktober 2016 Naskah Revisi : 12 Oktober $2016 \quad$ Naskah Diterima : 20 Oktober 2016

\begin{abstract}
Adolescent are the largest population of the target pornography. The purpose of this study were to describe the behavior of junior high school students in accessing pornography. The research method is descriptive quantitative research. The population are Junior High School (SMP) students in Pati regency in total 31.012.The sampel size is 395 students from 19 SMP. Teknik sampling using proportional random sampling area. This research was conducted in June to October 2015 . Data retrived by questionnaires in the form of closed questions. Data analyzed with descriptive analysis using SPSS 16. The results showed that $29.11 \%$ of respondents indicated behavioral accessing pornography, 67\% of respondents who accessed porn is male $77 \%$ and $33 \%$ female, most respondents grade 9 had been accessing pornography 62\%, the age of first accessing pornography mostly at the age of $12(27 \%)$ and 13tahun (27\%), media sources such as smartphone and VCD from friends (37\%) and the internet (35\%), where access to pornography is in the house as much as $48.7 \%$, while accessing pornography majority partner is a friend as much as $60.9 \%$, the response time of viewing pornography is largely disgusted as much as $41.7 \%$, reasons to access mostly for fun as much as $39.1 \%$.
\end{abstract}

Keywords: access, adolescent, pornografi,

\begin{abstract}
ABSTRAK
Remaja merupakan populasi terbesar yang menjadi sasaran pornografi. Penelitian ini dimaksudkan untuk mendapatkan gambaran secara kuantitatif tentang perilaku siswa SMP dalam mengakses materi pornografi.Penelitian ini merupakan penelitian kuantitatif deskriptif. Populasi penelitian adalah siswa siswi Sekolah Menengah Pertama (SMP) di Kabupaten Pati yang berjumlah 31.012.Sampel penelitian ini terdiri atas 395 siswa dari 19 SMP N yang bersedia menjadi responden penelitian.Teknik pengambilan sampel menggunakan proporsional area random sampling. Penelitian ini dilakukan pada bulan Juni sampai Oktober 2015.Pengambilan data penelitian dengan menggunakan angket berupa pertanyaan tertutup.Data dianalisis dengan analisis deskriptif dengan menggunakan bantuan SPSS 16. Hasil penelitian menunjukkan bahwa $29,11 \%$ responden menunjukkan perilaku mengakses meteri pornografi,67\% responden pengakses porno berjenis kelamin laki-laki $77 \%$ dan 33\% perempuan, sebagian besar responden kelas 9 sudah pernah mengakses materi porno yaitu 62\%, usia pertama kali mengakses pornografi sebagian besar pada usia 12\&13tahun yaitu 54\%, Sumber media berupa Hp dan VCD dari teman (37\%) dan internet (35\%), tempat mengakses materi pornografi adalah di rumah sebanyak 48,7\%, partner saat mengakses pornografi sebagian besar adalah teman sebanyak 60,9\%, respon saat melihat materi pornografi sebagian besar adalah jijik sebanyak 41,7\%, Alasan mengakses sebagian besar karena iseng/coba-coba sebanyak 39,1\%.
\end{abstract}

Kata kunci : perilaku, remaja, pornografi 


\section{PENDAHULUAN}

Kemajuan teknologi ibarat dua mata pisau, disisi lain menguntungkan, disisi lain bisa berbahaya. Salah satu dampak negatif kemajuan teknologi adalah mudahnya mengakses pornografi dan porno aksi yakni internet pornografi. Internet meliputi gadget dan smartphone yang banyak digunakan remaja dalam interaksi sosial (Suyatno, 2011). Hasil survei yang dilakukan oleh Kementrian Komunikasi dan Informasi (2009), Indonesia menempati peringkat pertama pengakses situs porno di dunia, pada tahun 2010 peringkat ke empat, dan tahun 2011 Indonesia menempati peringkat kedua terbesar di dunia sebagai pengakses situs porno dengan pertumbuhan $25 \%$ setiap tahunnya atau sekitar 45 juta jiwa (Purwadi, 2011).

Jumlah pengakses informasi erotis di media massa dari kalangan remaja semakin meningkat, dengan tingkatan keterpaparan yang semakin berat (Furwasih, 2011). Hal ini sejalan dengan hasil survei yang dilakukan oleh yayasan kita dan buah hati di jabodetabek dalam Supriati dan Fikawati (2009) terhadap 705 responden remaja memperoleh hasil bahwa lebih dari $80 \%$ anak usia 9-12 tahun telah mengakses materi pornografi melalui situs-situs internet.

Pornografi merupakan material berbau hal-hal seksual yang membangkitkan gairah seksual (Suyatno, 2011). Suyatno (2011) menyatakan lebih lanjut bahwa pornografi telah menjadi salah satu dalang rusaknya mentalitas generasi muda bangsa. Pornografi sangat mengkhawatirkan bagi remaja dan memberikan dampak yang buruk bagi remaja. Salah satu efek dari pornografi adalah kecanduan menikmati pornografi. Efek buruk lain dari pornografi di adalah kecenderungan perilaku beresiko sebagaimana ditunjukkan Nursal (2007) melalui penelitian bahwa responden yang terpapar pornografi melalui media elektronik mempunyai peluang 3,06 kali untuk berperilaku seksual beresiko jika dibandingkan dengan remaja yang tidak terpapar media elektronik. Sarwono (2012) menambahkan bahwa dampak negatif pornografi adalah kecenderungan perilaku seksual meningkat disebabkan oleh adanya penyebaran informasi dan rangsangan seksual melalui media elektronik yang sangat mudah diakses oleh para remaja. Tayangan media massa yang menonjolkan aspek pornografi diyakini sangat erat hubungannya dengan meningkatnya berbagai kasus kekerasan seksual yang terjadi pada remaja (Cerita Remaja Indonesia, 2001). Rangsangan kuat dari luar seperti film-film seks (blue film), sinetron, buku-buku bacaan dan majalah-majalah bergambar seksi, godaan dan rangsangan dari kaum pria, serta pengamatan secara langsung terhadap perbuatan seksual tidak hanya mengakibatkan memuncaknya atau semakin panasnya reaksi-reaksi seksual tetapi juga mengakibatkan kematangan seksual yang lebih cepat pada diri anak (Kartono, 2003).Dampaknya adalah makin aktifnya perilaku seksual pranikah yang disertai ketidaktahuan yang pada gilirannya bisa membahayakan kesehatan reproduksi remaja (Wirawan dalam Soekanto, 2005).

Hasil-hasil penelitian tersebut menyisakan banyak pertanyaan tentang keterpaparan pornografi siswa SMP di Kabupaten Pati. Kemudahan akses pornografi melalui HP, internet dan VCD/DVD bajakan telah menawarkan banyak alternatif bagi siswa yang mendapat pengawasan ketat di rumah.

Penelitian ini dimaksudkan untuk mendapatkan gambaran secara kuantitatif tentang perilaku siswa SMP dalam mengakses materi pornografi. Siswa SMP merupakan kelompok umur yang seharusnya terhindar dari materi 
pornografi, padahal kondisi di lapangan banyak sekali pada kelompok umur ini yang sudah terpapar materi pornografi sehingga sangat penting mengetahui bagaimana perilaku remaja dalam mengakses pornografi.

\section{TINJAUAN PUSTAKA}

\section{Pornografi}

Dalam Kamus Besar Bahasa Indonesia, pornografi diartikan sebagai : (1) Penggambaran tingkah laku secara erotis dengan lukisan atau untuk membangkitkan nafsu birahi, mempunyai kecenderungan merendahkan kaum wanita; (2) Bahan yang dirancang dengan sengaja dan semata-mata untuk membangkitkan nafsu seks.

Bungin (2005) menjelaskan pornografi adalah gambar-gambar perilaku pencabulan yang lebih banyak menonjolkan tubuh dan alat kelamin manusia. Sifatnya yang seronok, jorok, vulgar, membuat orang yang melihatnya terangsang secara seksual.

\section{Perilaku Mengakses Pornografi}

Remaja memiliki rasa ingin tahu yang besar, namun remaja justru kurang mendapatkan kurang mendapatkan informasi dan pengetahuan yang cukup berkaitan dengan seksualitas. Seringkali remaja merasa bahwa orang tuanya menolak mebicarakan masalah seks, merasa tidak nyaman atau tabu untuk membicarakan masalah seksualitas dan kesehatan reproduksinya. Untuk mememuhi rasa ingin tahuya, remaja mencari alternatif sumber informasi lain seperti teman atau media internet (Darwisyah, 2009). Rina dkk (2014) melalui penelitiannya menyatakan bahwa $97,5 \%$ remaja sudah mencari informasi tentang perilaku seksual. Lebih lanjut peneliti menyatakan bahwa $25 \%$ melalui internet, $20 \%$ melalui teman sebaya, $17 \%$ media cetak, dan $12,4 \%$ mencari melalui media elektronik.

\section{Karakteristik Remaja}

Remaja merupakan generasi harapan bangsa yang akan menentukan kehidupan keluarga, bangsa dan Negara di masa yang akan datang. Remaja dituntut memiliki potensi dalam membangun kehiduapan dan memiliki konsep diri yang positif untuk memahami dan mengenal dirinya.oleh karenanya, remaja mendapatkan perhatian khusus dari masyarakat dan pemerintah (BKKBN, 2014).

Batasan remaja dalam penelitian ini adalah remaja awal. Monks (2001) mengkategorikan fase remaja awal berada pada rentang usia 10-16 tahun. Monks (2001) menjelaskan lebih lanjut mengenai remaja bahwa pada umumnya, mereka masih belajar di sekolah menengah pertama Pada masa ini, anak mengalami masa perkembangan intelektualitas yang pesat, merasa tahu segalanya yang diwujudkan dalam bentuk membantah terhadap orang tua, mulai menyukai orang dewasa yang dianggap baik dan dijadikan "pujaan". Perkembangan emosional ditandai dengan emosi yang labil terutama berkaitan dengan seksualitasnya. Perasaan sosial berkembang semakin kuat, ditandai dengan semakin senang berkelompok dan membuat peraturan sesuai dengan pemikirannya sendiri.

\section{METODE PENELITIAN}

Penelitian ini merupakan
penelitian kuantitatif deskriptif.
Pendekatan kuantitatif ditujukan untuk
mengungkap perilaku mengakses materi


pornografi oleh pelajar tingkat SMP. Populasi penelitian adalah siswa siswi Sekolah Menengah Pertama (SMP) di Kabupaten Pati yang berjumlah 31.012. Sampel penelitian ini terdiri atas 395 siswa dari 19 SMP $\mathrm{N}$ yang bersedia menjadi responden penelitian. Teknik pengambilan sampel menggunakan proporsional area random sampling. Penelitian ini dilakukan pada bulan Juni sampai Oktober 2015. Pengambilan data penelitian dengan menggunakan angket berupa pertanyaan tertutup. Penyebaran kuesioner dilakukan oleh peneliti dengan masuk ke kelas didampingi dan atau dibantu oleh guru bimbingan konseling. Data dianalisis dengan analisis deskriptif dengan menggunakan bantuan SPSS 16, penyajian data berupa frekuensi dan persentase.

\section{HASIL DAN PEMBAHASAN}

\section{Identitas Responden}

Tabel 1 dapat digambarkan bahwa responden laki-laki berjumlah 201 siswa atau 50,9\% sedangkan responden perempuan berjumlah 194 siswa atau sama dengan 49,1\% dari total seluruh responden. Berdasarkan kelas, terbagi menjadi 3 jenjang yaitu kelas 7, 8 dan 9 dengan rincian kelas 7 sebanyak 150 siswa atau 38,0\%, kelas 8 sebanyak 103 siswa atau $26,1 \%$ dan kelas 9 sebanyak 142 atau 35,9\%. Dilihat dari usia, responden berada pada rentang usia 1116 tahun. Jumlah terbanyak terdapat pada kelompok usia 14 tahun sebanyak 175 siswa atau 44,3\% dan jumlah terkecil pada kelompok usia 11 tahun berjumlah 8 orang atau $1,7 \%$.

Tabel 1.

Sebaran Identitas Responden

\begin{tabular}{ccr}
\hline $\begin{array}{c}\text { Identitas } \\
\text { Responden }\end{array}$ & Frekuensi & $\begin{array}{c}\text { Persentase } \\
(\mathbf{\%})\end{array}$ \\
\hline Jenis Kelamin & & \\
Laki-laki & 201 & 50,9 \\
Perempuan & 194 & 49,1 \\
Kelas & $\mathbf{3 9 5}$ & $\mathbf{1 0 0 , 0}$ \\
7 & & \\
8 & 150 & 38,0 \\
9 & 103 & 26,1 \\
& 142 & 35,9 \\
Usia & $\mathbf{3 9 5}$ & $\mathbf{1 0 0 , 0}$ \\
11 & & \\
12 & 8 & 1,7 \\
13 & 51 & 13,0 \\
14 & 86 & 21,7 \\
15 & 175 & 44,3 \\
16 & 65 & 16,5 \\
& 10 & 2,6 \\
& $\mathbf{3 9 5}$ & $\mathbf{1 0 0 , 0}$ \\
\hline
\end{tabular}

Sumber : Pengolahan data, 2016 
HASIL DAN PEMBAHASAN

\section{Perilaku Mengakses Pornografi Elektronik}

Tabel 2, diketahui bahwa sebanyak 115 responden atau $29,1 \%$ dari total keseluruhan responden mengalami keterpaparan pornografi elektronik.
Wibowo (2004) menyatakan bahwa media massa elektronik dan media cetak memegang peranan yang tidak kecil dalam khayalan seksual remaja, karena informasi ini selain memperluas wawasan dan pengetahuan juga membawa nilai-nilai dari negara asal informasi tersebut.

Tabel 2.

Keterpaparan Pornografi Elektronik

\begin{tabular}{cccc}
\hline Variabel & Kategori & Frekuensi & \% \\
\hline Mengakses Pornografi Elektronik & Ya & 115 & 29,1 \\
& Tidak & 280 & 70,9 \\
& & $\mathbf{3 9 5}$ & $\mathbf{1 0 0 , 0}$
\end{tabular}

Sumber : Pengolahan data, 2016

\section{Perilaku Mengakses Pornografi Elektronik Berdasarkan Jenis Kelamin}

Tabel 3 menunjukkan bahwa perilaku mengakses pornografi elektronik lebih banyak dilakukan oleh remaja lakilaki yaitu sebanyak 77 responden atau $67,0 \%$ dari pada remaja perempuan sebanyak 38 responden atau 33,0\% dari jumlah total responden yang terpapar pornografi elektronik.
Menurut ASA Indonesia (2005) konsumen utama pornografi (baik dari majalah, internet, tabloid, dan lain-lain) adalah remaja laki-laki berusia 12 sampai 17 tahun. Malamuth et al (2007) meyatakan bahwa dalam beberapa penelitian, laki-laki lebih banyak menjadi konsumen berbagai jenis dari pada wanita.Pria juga lebih tertarik terhadap pornografi dan melakukannya secara rutin.

Tabel 3.

Perilaku Mengakses Pornografi Elektronik Berdasarkan Jenis Kelamin

\begin{tabular}{rccr}
\hline Variabel & Kategori & Frekuensi & \multicolumn{1}{c}{$\%$} \\
\hline Jenis kelamin & Laki-laki & 77 & 67,0 \\
& Perempuan & 38 & 33,0 \\
& & $\mathbf{1 1 5}$ & $\mathbf{1 0 0 , 0}$
\end{tabular}

Sumber : Pengolahan data, 2016

\section{Perilaku Mengakses Pornografi Berdasarkan Kelas}

Perilaku mengakses pornografi berdasarkan kelas disajikan pada Tabel 4 , menunjukkan bahwa perilaku mengakses pornografi elektronik sebagian besar dilakukan oleh siswa kelas 9 sebanyak 62 responden atau $53,9 \%$, kelas 8 sebanyak 33 responden atau $28,7 \%$ dan kelas 7 sebanyak 20 responden atau $17,4 \%$. Hal ini menunjukkan bahwa semakin tinggi jenjang kelas responden semakin besar peluang untuk mengakses materi pornografi melalui elektronik. 
Tabel 4.

Perilaku Mengakses Pornografi Berdasarkan Kelas

\begin{tabular}{lccr}
\hline Variabel & Kategori & Frekuensi & \multicolumn{1}{c}{} \\
\hline Kelas & 7 & 20 & 17,4 \\
& 8 & 33 & 28,7 \\
& 9 & 62 & 53,9 \\
& & $\mathbf{1 1 5}$ & $\mathbf{1 0 0 , 0}$ \\
\hline
\end{tabular}

Sumber : Pengolahan data, 2016

\section{Usia Pertama kali Mengakses Pornografi Elektronik}

Tabel 5 menunjukkan bahwa usia pertama kali mengakses materi pornografi sangat beragam, berada pada rentang usia 8tahun sampai usia 15 tahun. Meskipun demikian, sebagian besar responden mengakses pornografi pada usia $12(23,5 \%)$ \& 13 tahun $(23,5 \%)$.
Penelitian ini sejalan dengan hasil survei di tahun 2005 yang dilakukan oleh Yayasan Kita dan Buah Hati di Jabodetabek terhadap 705 responden remaja memperoleh hasil bahwa lebih dari $80 \%$ anak usia 9-12 tahun telah mengakses materi pornografi melalui situs-situs internet (BKKBN dalam Marlia, 2015).

\section{Tabel 5.}

Usia Pertama kali Mengakses Pornografi Elektronik

\begin{tabular}{cccc}
\hline Variabel & Kategori & Frekuensi & \% \\
\hline Pertama kali Mengakses & 8 th & 3 & 2,6 \\
Pornografi & 9 th & 4 & 3,5 \\
& 10 th & 5 & 4,3 \\
11 th & 16 & 13,9 \\
12 th & 27 & 23,5 \\
13 th & 27 & 23,5 \\
& 14 th & 10 & 8,7 \\
15 th & 3 & 2,6 \\
& Tidak menjawab & 20 & 17,4 \\
& & $\mathbf{1 1 5}$ & $\mathbf{1 0 0 , 0}$ \\
\hline
\end{tabular}

Sumber : Pengolahan data, 2016

\section{Sumber Media Pornografi Elektronik}

Sumber media pornografi elektronik disajikan pada Tabel 6, memperlihatkan bahwa sumber media yang digunakan adalah Smartphone (HP yang memiliki fasilitas internet) dan VCD yang berasal dari teman, sebanyak 37 responden atau 32,2\% ; dari internet sebanyak 35 responden atau 30,4\% dan sendiri sebanyak 21 responden atau $18,3 \%$. Beberapa responden mengaku mengakses materi pornografi melalui lebih dari satu jenis sumber media.
Media yang sering digunakan oleh remaja seperti situs porno (internet), video, film porno, serta smartphone (Sarwono, 2012). Kehadiran media komunikasi seperti smartphone yang hampir dimiliki setiap orang, termasuk remaja, disamping memberikan keuntungan juga memberikan dampak negatif. Smartphone dapat dijadikan ajang tukar-menukar informasi dengan saling mengirim SMS/MMS, WA beserta gambar porno yang tidak layak ditonton. Perkembangan lainnya melalui 
internet yang telah begitu luas dan bebasnya diakses oleh remaja. Kemajuan teknologi ibarat dua mata pisau, disatu sisi sangat menguntungkan, disisi lain bisa berbahaya. Salah satu dampak negatif dari kemajuan teknologi berupa internet adalah mudahnya mengakses pornografi dan pornoaksi yakni internet pornografi (Suyatno, 2011).
Hal tersebut menjadikan remaja mendapatkan paparan pornografi dengan cara yang mudah, murah dan bersifat pribadi. Sebaliknya bagi orang tua akan sangat menyulitkan untuk menghindarkan dan melakukan pengawasan terhadap anak remajanya terpapar dengan pornografi.

Tabel 6.

Sumber Media Pornografi Elektronik

\begin{tabular}{clcr}
\hline Variabel & \multicolumn{1}{c}{ Kategori } & Frekuensi & \% \\
\hline Sumber Media & Internet & 35 & 30,4 \\
& HP sendiri & 21 & 18,3 \\
& Hp dan VCD dari teman & 37 & 32,2 \\
& HP orang tua/kakak & 3 & 2,6 \\
& TV dirumah & 5 & 4,3 \\
& HP sendiri dan Ortu & 1 & 0,9 \\
TV dan VCD teman & 2 & 1,7 \\
& Internet, HP teman dan & 2 & 1,7 \\
Ortu & 7 & 6,1 \\
& TV dan Internet & 2 & 1,7 \\
Tidak menjawab & $\mathbf{1 1 5}$ & $\mathbf{1 0 0 , 0}$ \\
\hline
\end{tabular}

Sumber : Pengolahan data, 2016

\section{Tempat Mengakses Pornografi Elektronik}

Tempat mengakses pornografi elektronik disajikan pada Tabel 7, dapat dilihat bahwa sebagian besar responden mengakses materi pornografi dirumah sendiri sebanyak 56 responden atau
48,7\%, kemudian diikuti di warnet sebanyak 32 responden atau 27,8\% dan di rumah teman sebanyak 13 responden atau $11,3 \%$. Tempat lain yang digunakan untuk mengakses materi pornografi antara alain di sekolah, dilapangan, dan di warnet maupun rumah teman.

Tabel 7.

Tempat Mengakses Pornografi Elektronik

\begin{tabular}{clcr}
\hline Variabel & \multicolumn{1}{c}{ Kategori } & Frekuensi & \% \\
\hline Tempat & Di rumah & 56 & 48,7 \\
& Warnet & 32 & 27,8 \\
& Sekolah & 4 & 3,5 \\
& Rumah dan warnet & 3 & 2,6 \\
& Rumah teman & 13 & 11,3 \\
& Lapangan & 1 & 0,9 \\
& Warnet dan rumah teman & 1 & 0,9 \\
& Tidak menjawab & 5 & 4,3 \\
& & $\mathbf{1 1 5}$ & $\mathbf{1 0 0}$ \\
\hline
\end{tabular}

Sumber : Pengolahan data, 2016 


\section{Partner Mengakses Pornografi Elektronik}

Tabel 8 menunjukkan bahwa sebagian besar responden mengakses materi pornografi bersama dengan teman sebanyak 70 responden atau 60,9\%; sendiri sebanyak 29 responden atau $25,2 \%$, bersama suadara, sendiri dan juga teman, teman dan pacar dan ada juga yang tidak mau menjawab.

Tabel 8.

Partner Mengakses Pornografi

\begin{tabular}{clcr}
\hline Variabel & \multicolumn{1}{c}{ Kategori } & Frekuensi & \% \\
\hline Partner & Sendiri & 29 & 25,2 \\
& Teman & 70 & 60,9 \\
& Sendiri dan teman & 3 & 2,6 \\
& Saudara & 4 & 3,5 \\
& Teman dan pacar & 1 & 0,9 \\
& Tidak menjawab & 8 & 7,0 \\
& & $\mathbf{1 1 5}$ & $\mathbf{1 0 0 , 0}$ \\
\hline
\end{tabular}

Sumber : Pengolahan data, 2016

Ikatan emosi dan konformitas kelompok pada remaja sangat kuat, maka biasanya hal ini sering dianggap juga sebagai faktor yang menyebabkan munculnya tingkah laku remaja yang buruk (Sarwono, 2011). Konformitas kelompok bisa berarti kondisi dimana seseorang mengadopsi sikap atau perilaku dari orang lain dalam kelompoknya karena tekanan dari kenyataan atau kesan yang diberikan oleh kelompoknya tersebut (Santrock, 2007).

\section{Respon Ketika Pertama Kali Melihat Materi Pornografi}

Berdasarkan Tabel 9, dapat dilihat bahwa respon sebagian besar responden adalah merasa jijik ditunjukkan dengan jawaban sebanyak 48 responden atau $41,7 \%$, kemudian kaget sebanyak 26 responden atau 22,6\%. Respon lainnya diantaranya kaget dan juga jijik, penasaran, terangsang, ketagihan, biasa saja, langsung pergi, penasaran dan ketagihan.

Tabel 9.

Respon Ketika Melihat Pornografi Elektronik

\begin{tabular}{clcr}
\hline Variabel & \multicolumn{1}{c}{ Kategori } & Frekuensi & \% \\
\hline Respon Ketika terpapar & Terangsang & 2 & 1,7 \\
& Kaget & 26 & 22,6 \\
& Penasaran & 6 & 5,2 \\
& Ketagihan & 2 & 1,7 \\
& Jijik & 48 & 41,7 \\
& Kaget dan jijik & 14 & 12,2 \\
& Terangsang, penasaran, jijik & 2 & 1,7 \\
& Biasa & 3 & 2,6 \\
& Penasaran dan ketagihan & 1 & 0,9 \\
& Langsung pergi & 1 & 0,9 \\
& Terangsang, kaget, penasaran, & 1 & 0,9 \\
& ketagihan & & 7,8 \\
& Tidak menjawab & 9 & $\mathbf{1 0 0 , 0}$ \\
\hline
\end{tabular}

Sumber : Pengolahan data, 2016 


\section{Alasan Mengakses Pornografi Elektronik}

Tabel 10 menunjukkan bahwa sebagian besar responden mengaku alasan mengakses materi pornografi karena iseng atau coba-coba sebanyak 45 responden atau $39,1 \%$. alasan lain adalah karena iseng dan diajak teman sebanyak 25 responden atau $21,7 \%$, diajak teman sebanyak 17 responden atau 14,8\%.

Tabel 10.

Alasan Mengakses Pornografi Berdasarkan Kelas

\begin{tabular}{clcr}
\hline Variabel & \multicolumn{1}{c}{ Kategori } & Frekuensi & \% \\
\hline Alasan & Iseng/coba-coba & 45 & 39,1 \\
& Menambah wawasan & 9 & 7,8 \\
& Diajak teman & 17 & 14,8 \\
& Iseng dan diajak teman & 25 & 21,7 \\
& Iseng dan menambah wawasan & 1 & 0,9 \\
& Iseng, diajak teman, dan menambah & & 0,9 \\
& wawasan & 1 & 14,8 \\
& Tidak menjawab & 17 & $\mathbf{1 0 0 , 0}$ \\
\hline
\end{tabular}

Sumber : Pengolahan data, 2016

\section{KESIMPULAN DAN SARAN}

\section{Kesimpulan}

Hasil penelitian menunjukkan bahwa $29,11 \%$ responden menunjukkan perilaku mengakses meteri pornografi, $67 \%$ responden pengakses porno berjenis kelamin laki-laki sebanyak $77 \%$ dan $33 \%$ perempuan. Semakin tinggi kelas, semakin tinggi pula persentase anak yang mengakses materi porno, dimana persentase tertinggi anak yang mengakses materi porno berada pada kelas 9 (62\%). Usia pertama kali mengakses pornografi sebagian besar pada usia $12 \& 13$ tahun yaitu masingmasing 27\%. Media yang digunakan untuk mengakses materi porno adalah HP dan VCD yang didapatkan dari teman $(37 \%)$ dan dari internet (35\%). Tempat mengakses materi pornografi adalah di rumah sebanyak 48,7\%. Sebagian besar anak mengakses materi porno secara kolektif, dengan persentase bersama teman merupakan yang tertinggi $(60,9 \%)$. Respon pertamakali saat melihat materi pornografi sebagian besar adalah jijik sebanyak 41,7\%, Alasan mengakses sebagian besar karena iseng/coba-coba sebanyak 39,1\%.

\section{Saran}

\section{Orang Tua}

1. Memperbaiki pola pengasuhan terutama pengawasan dan komunikasi terbuka kepada anak baik secara umum maupun khusus mengenai seksualitas sesuai dengan tahapan usia. Hal ini untuk menciptakan suasana kondusif dalam keluarga sehingga anak dapat berperilaku sesuai dengan norma dikeluarga/dirumah.

2. Mengoptimlkan peran orang tua dalam memberikan pendidikaan seks sejak dini. Ayah dapat mendampingi anak laki-laki untuk mempersiapkan anak pubertas yang ditandai dengan mimpi basah serta transfer 
pengetahuan seksualitas secara umum. Sedangkan untuk anak perempuan dapat didampingi oleh ibu. Jika pada kondisi yang tidak ideal dalam keluarga maka proses pendampingan persiapan pubertas dapat di lakukan oleh pengasuh pengganti ortu.

3. Mempersiapkan kematangan moralitas, yang ditandai anak dapat membedakan mana yang baik dan mana yang buruk (harus dihindari) sebelum memutuskan untuk memberikan fasilitas smartphone dan pengenalan internet

\section{Sekolah}

1. Peraturan dan pengawasan untuk tidak membawa smartphone di sekolah.

2. Bekerjasama dengan instansi terkait untuk melakukan sosialisasi mengenai bahaya pornografi, penggunaan smartphone dan internet secara bijak.

3. Guru dapat menjadi sahabat untuk siswa sebagai sumber informasi yang tepat dalam mencari referensi mengenai hal-hal yang berkaitan dengan seksualitas peserta didik.

\section{Pemerintah}

1. Peran pemerintah untuk memblokir situs-situs porno melalui internet.

\section{DAFTAR PUSTAKA}

Aliansi Selamatkan Anak Indonesia. 2005. Remaja Dalam Angka. http://asa-

indonesia.com/asa/index.php?item $i d=4$. Diakses tanggal 9 Maret 2015 .

Badan Kependudukan dan Keluarga Berencana Nasional. 2014. Anak Indonesia Rentan Pornografi .Http://Hqweb01.Bkkbn.Go.Id/Arti
cle_Detail.Pihp?Aid=531.2004.di akses tanggal 5 januari 2016.

Bugin, Burhan. 2005. Konstruksi Sosial Media Massa. Jakarta : Kencana.

Cerita Remaja Indonesia. 2001. Materi yang Menonjolkan Seks di Media. Http://Hqweb01.Bkkbn.Go.Id/Hqw eb/Ceria/Mblmateriseksual.Html. diakses tanggal 7 Februari 2015.

Darwisyah,S. 2009. Seksualitas Remaja Indonesia.

http://www.kesrepro.info/?q=mod e/366. Diakses tanggal 16 Januari 2015.

Furwasih, D. 2011. Hubungan Frekuensi Keterpaparan Informasi Erotis di Televisi dan Internet Dengan Perilaku Seksual Remaja Dalam Berpacaran Di SMK Satya Widya Kota Surabaya Tahun 2011. http://journal.mercubaktijaya.ac.i d/abstract-47.html. Diakses tanggal 3 Maret 2016.

Kartono, K. 2003. Patologi Sosial. Jakart: Raja Grafindo Persada.

Malamuth, Neil, Ed. Roy F. Baumeister; Kathleen D.Vosh. 2007. Pornograph. Encyclopedia of Social Psychology. California : Sage Publications Inc.

Marlia, Tutin. 2015. Faktor-faktor yang berhubungan dengan praktik hubungan seksual pranikah pada remaja di salah satu SMA di Indramayu. Prosiding seminar nasional penelitian dan PKM Kesehatan.Bandung, 125-134.

Monks,F.J., A.M.P. Knoers dan S.R. Hadinoto. 2001. Psikologi Perkembangan: Pengantar dalam Berbagai Bagiannya. Yogyakarta: Gajah Mada University Press.

Nursal, Dien G A. 2007. Faktor-faktor yang berhubungan dengan Perilaku Seksual Murid SMU 
Negeri di Kota padang Tahu 2007. Artikel Penelitian. Fakultas Kedokteran. Padang : Universitas Andalas

Purwadi, Didi. 2011. Indonesia Pengakses Situs Porno Terbesar Di Dunia. http//: republika.co.id/berita/nasional/um um/11/5/524/llowd-tifatul-efekiternet-tergantung-iman. Diakses tanggal 1 januari 20015.

Rina, Dewi, Hasneli. 2014. FaktorFaktor yang mempengaruhi sikap remaja tentang seks Pranikah. Prodi Ilmu Keperawatan. Sripsi. Pekanbaru : Universitas Riau.

Soekanto, S. 2005. Remaja Dalam Angka. Http://AsaIndonesia.Com/Asa/Index.Php? Ite mid=4. Diakses tanggal 7 Februari 2016.

Santrock, J.W. 2007. Remaja, Edisi Kesebelas, Jilid I. Jakarta : Erlangga.

Sarwono, S.W. 2011. Psikologi Remaja, Edisi Revisi. Jakarta: Raja Grafindo Persada.
2012. Psikologi Remaja. Jakarta : Rajawali Pers.

Suyatno. 2011. Belajar Sendiri Mengenai Internet Jaringan Informasi Dunia. Jakarta : Ghalia Indonesia.

Supriati, E dan Fikawati, S. 2008. Efek Paparan Pornografi Pada Remaja SMP Negeri Kota Pontianak Tahun 2008. Makara Sosial Humaniora, Vol.13 No.1, Juli 2009: 48-56

Wibowo, A. 2004. Permasalahan Reproduksi Remaja dan Alternatif Jalan Keluarnya. Http://Www.Bkkbn.Go.Id. Diakses tanggal 21 Mei 2016.

\section{BIODATA PENULIS}

Siti Qorrotu Aini, lahir 5Agustus 1985 di Pati Jawa Tengah.Pendidikan Program Psikologi Universitas Diponegoro tahun 2009.Saat ini bekerja sebagai Peneliti di Kantor Penelitian dan Pengembangan Kabupaten Pati. 